\title{
INOVASI OLAH PANGAN DARI SINGKONG DI DESA PAK BULU KALIMANTAN BARAT
}

\author{
Innovation of Food From Cassava in Pak Bulu Village West Kalimantan
}

\author{
Agato dan Kardison Lumban Batu \\ Politeknik Negeri Pontianak, Jurusan Teknologi Pertanian dan Administrasi Bisnis, \\ Jalan Jenderal Ahmad Yani Pontianak, Kalimantan Barat \\ email : agato2006@yahoo.com
}

\begin{abstract}
Cassava is a local commodity of Desa Bulu Kalimantan Barat which has the potential to be developed in improving the economy of the community. During this time the village community Pak Bulu choose to sell cassava and use as livestock because of lack of knowledge and skills to cultivate cassava into an attractive food product, quality and economic value. Community service activities (PKM) become a forum for education and improvement of appropriate skills for rural areas. Individual approach and material simplification become methods in the implementation of PKM.Memberikan post-harvest technology information technology, business opportunities and training in processing cassava as an innovation of cassava is expected Can form the village community Pak Bulu creative, innovative and productive in deceiving the potential of local commodities.Mas Desa Village Bulu who have the skills in as an innovation of food cassava is an effort to achieve a prosperous society.
\end{abstract}

Keywords: food innovation, local commodity, cassava, post harvest

\begin{abstract}
ABSTRAK
Singkong merupakan komoditi lokal Desa Pak Bulu Kalimantan Barat yang berpotensi untuk dikembangkan dalam meningkatkan ekonomi masyarakat. Selama ini masyarakat Desa Pak Bulu memilih menjual singkongsegardan memanfaatkan sebagai pakai ternak karena kurangnya pengetahuan dan ketrampilan untuk mengolah singkong menjadi produk pangan yang menarik, berkualitas dan bernilai ekonomi. Kegiatan pengabdian kepada masyarakat (PKM) menjadi wadah pendidikan dan peningkatan ketrampilan yang tepat bagi daerah pedesaan.Pendekatan individu dan penyederhanaan materi menjadi metode dalam pelaksanaan PKM.Memberikan informasi teknologi pasca panen singkong, peluang usaha dan pelatihan dalam mengolah singkong sebagai inovasi olah pangan singkong diharapkan dapat membentuk masyarakat Desa Pak Bulu yang kreatif, inovatif dan produktif dalam memperdayakan potensi komoditi lokal.Masyarakat Desa Pak Bulu yang memiliki ketrampilan dalam sebagai inovasi olah pangan singkongmerupakan usaha untuk mencapai masyarakat yang sejahtera.
\end{abstract}

Kata Kunci: inovasi olah pangan, Komoditi lokal, singkong, pasca panen

\section{PENDAHULUAN}

Secara umum, proyeksi struktur ekonomi Kabupaten Mempawah pada lima tahun terakhir dominan pada sektor pertanian, yaitu rerata $27,12 \%$. Kecamatan Anjongan sebagai bagian dari Kabupaten Mempawah berperan besar dalam menunjang perkembangan sektor pertanian.
Kabupaten Mempawah dengan memiliki bentangan hutan rakyat seluas 423 ha, perkebunan 1.604 ha, hutan negara 2.257 ha, lahan belum diusahakan 32 ha dan lain-lain 13.339 ha (Bapeda Kabupaten Pontinak, 2008) sangat potensial dalam pengembanan komoditi lokal. Komoditi pertanian yang banyak dikembangkan di Kabupaten Mempawah meliputi kelapa sawit, kelapa, nenas, singkong, padi dan palawija. 
Kabupaten Mempawah membudidayakan komoditi pertanian dan perkebunan. Untuk pertanian, khususnya ubi kayu (singkong) Kabupaten Mempawah memproduksi 10.501 ton pada tahun 2012 (BPS Kalbar, 2014). Kecamatan Anjongan merupakan pemekaran dari Kecamatan Sungai Pinyuh yang meliputi Desa Anjongan Dalam, Anjongan Melanjar, Dema, Kepayang dan Pak Bulu. Desa Pak Bulu merupakan salah satu desa di Kecamatan Anjongan yang memiliki adminitrasi desa yang baik, aktif dalam kegiatan pengembangan desa untuk meningkatkan kualitas manusia, kompak dalam kegiatan bermasyarakat dan giat dalam peningkatan sektor pertanian.

Kelompok ibu PKK dan kelompok tani merupakan organisasi di Desa Pak Bulu yang memiliki program kerja dan aktif berkegiatan sehingga layak menjadi wadah yang baik dalam pengembangan potensi keahlian dalam pengolahan produk pangan komoditi lokal yaitu singkong. Kelompok ibu PKK dan kelompok tani ini berperan dalam usaha pengembangan masyarakat.

Singkong (Manihot esculanta L) menjadi bahan pangan pokok setelah beras dan jagung di Indonesian. Singkong merupakan sumber karbohidrat yang juga mengandung protein, Ca, B1, B2, Vitamin C dan kalori (Chan, 1983). Proses ektraksi singkong relatif lebih mudah karena mengandung protein dan lemak yang rendah dan jika diproses dengan baik, akan dihasilkan pati yang bersih dan putih yang dapat diaplkasikan dalam pembuatan kue (Moorthy, 2004). Singkong terdiri dari daging singkong dan 15-20\% berupa kulit yang dianggap sebagai limbah. Kulit singkong bagian dalam yang dianggap sebagai limbah masih mengandung nutrisi seperti serat kasar, Ca dan Protein sehingga layak diolah menjadi produk pangan (Arifin, 2005). Kulit singkong yang dikeringkan dapat diolah menjadi tepung (Rukmana, 1997). Usaha untuk dapat mengolah singkong menjadi produk pangan berupa rengginang singkong, pati, cake, cookies dan sambal goreng kulit singkong sangat diharapkan oleh masyarakat Desa Pak Bulu yang ingin diwujudkan oleh tim kegiatan IbM dalam inovasi olah pangan dari singkong Desa Pak Bulu.

Pada kegiatan Pengabdian kepada masyarakat ini, mitra kerja yang dipilih yaitu kelompok ibu PKK dankelompok tani Putik Sari. Dua kelompok organisasi masyarakat yang ada di Desa Pak Bulu ini dinilai dapat membantu keberlanjutan kegiatan dan mengembangkan ketrampilan pada kelompok lainnya.

\section{BAHAN DAN METODE}

\section{Bahan}

Bahan yang digunakan pada kegiatan pengabdian masyarakat meliputi; singkong, gula pasir, telur ayam, minyak goreng, margarine, baking powder, vanili, garam, butter, terigu, tepung sagu, cengkeh, kayu manis, susu bubuk dan susu kental, bawang merah, bawang putih, cabe, keju.

\section{Alat}

Alat yang digunakan pada kegiatan pengabdian masyarakat meliputi: blender, oven, mixer, pisau, loyang tipis, ayakan plastik, toples, cetakan kue basah, nampan plastik, baskom, sendok, garpu, panci pengukus dan perebus, kompor gas yang dilengkapi selang dan tabung gas, sutil, botol saus, teko ukur, kuali, talenan, serbet, timbangan, sealer dan plastik, pencetak rengginan, ayakan.

\section{Metode Pelaksanaan}

Metode pelaksanaan kegiatan dilaksanakan dalam dua tahapan, yaitu penyuluhan dan praktek pembuatan produk (demontrasi produk). Penyuluhan dilakukan pada seluruh peserta, termasuk menjelaskan proses kerja pembuatan produk secara menyeluruh. Pada tahapan pembuatan produk, peserta dibagi menjadi 4 kelompok untuk membuat produk yang berbeda dan pengemasan produk dengan pengawasan tim pelaksana. Pada akhir kegiatan, peserta mengisi kuisioner yang disiapkan tim 
pelaksana PKM. Seluruh peralatan dan bahan produksi disediakan oleh tim pelaksana PKM untuk selanjutnya diserahkan kepada mitra kerja sebagai modal keberlanjutan kegiatan.

\section{HASIL DAN PEMBAHASAN}

Dalam pelaksanaan kegiatan dilaksanakan pembuatan lima (5) produk olahan nenas. Pada akhir kegiatan, di-lakukan pengisian kuisioner untuk 20 peserta yang mengikuti kegiatan.Hasil kuisioner diuraikan pada Tabel 1, 2 dan 3.

Kegiatan PKM yang dilaksanakan merupakan bentuk pendidikan dan pelatihan singkat bagi masyarakat Desa Pak Bulu. Masyarakat Desa Pak Bulu yang terampil dalam inovasi produk pangan dari singkong merupakan hasil dari kegiatan PKM. Harapan dari kegiatan PKM ini adalah masyarakat Desa Pak Bulu yang mampu mengembangkan potensi lokal daerah untuk meningkatkan ekonomi masyarakat.

Sebelum kegiatan dilaksanakan, peserta tidak terampil bahkan tidak mengenal produk keripik sambal kulit singkong. Selama ini kulit singkong hanya dibuang sebagai limbah.Terdapat $25 \%$ peserta yang pernah membuat cake dan 15 $\%$ pernah membuat cookies tetapi tanpa penambahan singkong (tabel. 1).20\% peserta menyatakan dapat membuat rengginang singkong bahkan menjadikan produk yang dapat dijual. Kelemahan produk yang dibuat adalah tampilan fisik dan pengemasan yang kurang menarik sehingga masih perlu pem-bimbingan dalam pelatihan PKM ini.

Hasil pelatihan memberikan sumbangsih ilmu dan ketrampilan bagi peserta. Seluruh peserta merasa dapat membuat inovasi produk pangan singkong dengan hasil yang baik (Gambar. 1). Cake dan cookies yang dibuat menarik secara fisik, memiliki citra rasa dan aroma singkong serta tektur yang lembut untuk cake, renyah untuk cookies. Rengginang singkong memiliki warna yang lebih menarik dengan penambahan warna alami dan warna makanan serta pengemasan dengan menggunakan alat pengemasan yang dilatih dalam penggunaannya. Pati yang dihasilkan berwarna putih dan memiliki kehalusan standard karena diayak menggunakan ayakan mesh 80. Keripik sambal kulit singkong yang belum dikenal sebelum pelatihan menjadi produk favorit bagi peserta dengan rasa gurih dan enak. Pada kegiatan pengabdian kepada masyarakat ini, tim pelaksana mengarahkan peserta untuk menilai produk yang dihasilkan sehingga kelayakan produk tersebut dapat memotivasi peserta untuk pengembangan produk.

Tabel 1. Ketrampilan peserta mengolah produk pangan sebelum kegiatan

\begin{tabular}{cccccc}
\hline Produk & Rengginang & Cake & Pati & Cookies & $\begin{array}{c}\text { Kerupuk } \\
\text { sambal kulit } \\
\text { singkong }\end{array}$ \\
\hline Keterangan peserta & & & & & 0 \\
Terampil & 4 & 5 & 2 & 3 & 20 \\
\hline Tidak Terampil & 16 & 15 & 18 & 17 & 0 \\
\hline
\end{tabular}

Tabel 2. Ketrampilan peserta mengolah produk kuliner sesudah kegiatan

\begin{tabular}{lccccc}
\hline \multicolumn{1}{c}{ Produk } & Rengginang & Cake & Pati & Cookies & $\begin{array}{c}\text { Kerupuk } \\
\text { sambal kulit } \\
\text { singkong }\end{array}$ \\
\hline Keterangan peserta & 20 & 20 & 20 & 20 & 20 \\
Terampil & 0 & 0 & 0 & 0 & 0 \\
Tidak Terampil & & & & & \\
\hline
\end{tabular}


Tabel 3. Pendapat peserta tentang produk yang dihasilkan

\begin{tabular}{lccccc}
\hline \multicolumn{1}{c}{ Produk } & Rengginang & Cake & Pati & Cookies & $\begin{array}{c}\text { Kerupuk } \\
\text { sambal kulit } \\
\text { singkong }\end{array}$ \\
\hline Keterangan peserta & 0 & 5 & 10 & 4 & 10 \\
MBE & 20 & 15 & 10 & 16 & 10 \\
TMBE & & & & & \\
\hline
\end{tabular}

Keterangan :

MBE adalah menarik dan bernilai ekonomi

TMBE adalah tidak menarik dan tidak bernilai ekonomi

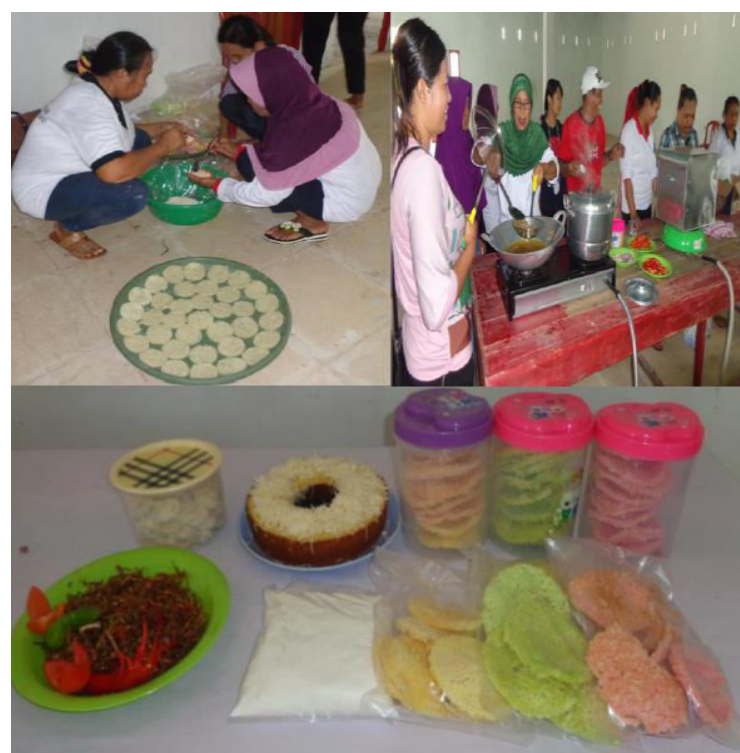

Gambar.1 Kegiatan produksi dan 5 produk yang dihasilkan

Secara umum peserta menyukai produk yang dibuat dalam kegiatan dan menilai bahwa produk memiliki nilai ekonomi. Peserta sangat tertarik dan menilai memiliki nilai ekonomi untuk produk rengginang singkong mencapai 100\% (Tabel.3). Peserta menilai dengan pembimbingan cara pengemasan dan perbaikan bentuk fisik rengginang singkong memberi nilai lebih untuk produk yang sebelumnya sudah dijual oleh beberapa peserta. Walaupun menilai secara ekonomis dinilai hanya $50 \%$ peserta (Tabel.3), keripik sambal kulit singkong dianggap menjanjikan oleh peserta karena enak dikosumsi untuk keluarga dan kulit singkong berlimpah dan sebelumnya hanya limbah. Peserta menilai produk cookies dan cake sekitar $75 \%$. Tampilan produk, rasa dan aroma produk menarik dan layak untuk dijual.Minat untuk menjual pati dianggap paling rendah yaitu 50\%. Hal tersebut dinilai oleh peserta bahwa membuat pati lebih dipilih untuk bahan pembuat produk jadi daripada untuk dijual. Keberlanjutan kegiatan terus dipantau oleh tim pelaksana PKM untuk membantu masyarakat Desa Pak Bulu dalam mengembangkan produk unggulan daerah berbahan komoditi lokal daerah.

\section{KESIMPULAN}

Berdasarkan evaluasi tim pelaksana kegiatan pengabdian kepada masyarakat, maka dapat disimpulkan:

1. Kegiatan pengabdian kepada masyarakat di Desa Pak Bulu berlangsung sesuai rencana dengan dukungan mitra kerja dan pejabat Desa.

2. Peserta sebagai mitra kerja dapat menguasai seluruh proses pengolahan produk yang disampaikan saat pelaksanaan kegiatan oleh tim pelaksana Politeknik Negeri Pontianak.

3. Peserta sebagai mitra kerja memiliki kemampuan dalam menggunakan dan merawat peralatan produksi.

\section{DAFTAR PUSTAKA}

Arifin. (2005). Kandungan gizi pada ubi kayu. Jurnal Ilmu-Ilmu Peternakan, IX (2): 90-110.

Badan Pusat Statistik Kabupaten Pontinak. (2012). Gambaran Umum Kondisi Daerah. 
Bappeda Kabupaten Pontinak. (2008). Moorthy. S. (2004). Tropical Sources Of Analisa Isu-Isu Strategis Starch.CRC Press.Baco Raton Florida.

Badan Pusat Statistis Kalimantan barat. Rukmana, R. (1997). Singkong, Budidaya (2014). Komoditi Unggulan Daerah. dan Pascapanen. Kanisius, Jakarta.

Chan H T. (1983). Handbook of Tropical Foods. Marcel Dekker Inc. New york and Bassel. 